811.163.41'354"18/20"

https://doi.org/10.18485/msc.2017.46.1.ch29

Вељко Ж. БРБОРИЋ*

Оригинални научни рад

Универзитет у Београду

Примљен: 03. 04. 2017.

Филолошки факултет

Прихваћен: 13. 04. 2017.

\title{
ПРАВОПИСНА СТАБИЛНОСТ СРПСКОГ ЈЕЗИКА И УТИЦАЈ ЈЕЗИКА У ОКРУЖЕЬУ
}

\begin{abstract}
У раду се говори о историји српског правописа и његовој правописној стабилности - како се до ње дошло, као и о ранијем утицају на новонастале језике у окружењу (хрватски, бошњачки и црногорски). Крајем XIX века модел Вуковог правописа преузет је у окружењу и у целини прихваћен стварањем прве Југославије и именовањем језика „српскохрватски". Ипак, крајем XX века на простору бившег српскохрватског језика настају национални језици и национални правописи као резултат настанка нових (националних) држава. Покушаћемо да у раду покажемо колико је та ситуација утицала на правописну норму српског језика, до којих промена је дошло и какав је њихов карактер у Правопису српског језика (2010). Истовремено ћемо констатовати да разлике међу новонасталим (националним) правописима нису велике.
\end{abstract}

Кључне речи: српски језик, правопис, правописна стабилност, језици у окружењу

\section{1. Увод}

Вукова правописна реформа, ослоњена на народни језик, до кодификације је долазила одабиром најпогоднијих образаца из народног говора, избором азбуке од 30 гласовних јединица и већ познатим принципом да се речи пишу сагласно свом гласовном и изговорном склопу. У књизи Српски језик на крају века Митар Пешикан је изнео став да се српски правопис и његова решења нису променила од Вука до данас. Ова тврдња М. Пешикана је тачна, мада се мора рећи да се од Вука до данас српски правопис мењао, односно да су неке правописне области доживеле извесне модификације. Заправо, неке правописне области од Вука до данас имале су озбиљан развој. Најбољи пример такве тврдње је писање имена и речи из страних језика.

*Brboricv@eunet.rs 
Реформишући српски језик и правопис Вук је, бар тако данас изгледа, реформисао и језике у окружењу, тј. њихове правописе. Наиме, Вук Караџић је својом правописном реформом директно и индиректно реформисао и језике којима се данас говори у три бивше истојезичне републике, данас самосталне државе (Хрватска, Босна и Херцеговина и Црна Гора). Заправо, оне су преузеле Вуков модел.

Вук је реформу учинио јавном 1818. године у знаменитом Српском рјечнику, који ни после два века није изгубио актуелност, па то дело и даље представља неку врсту српског језичког и правописног камена темељца. Можемо рећи да је правописна стабилност код Срба била успостављена у другој половини деветнаестог века, када је Вукова реформа оснажена, и то на два начина. Први се огледа у званичном прихватању Вукове реформе, али је за то од појаве Српског рјечника било потребно пуних педесет година (1868). Други начин представља објављивање књига, и језичких и правописних, које подржавају Вуков рад и снаже Вукову правописну реформу. Таквих књига је било доста и у Србији и у окружењу (изван Србије).

По тумачењу Милорада Радовановића процес планирања језика и прихватања изабраног језичког модела одвија се у континуираном процесу. Он наводи десетак фаза, односно поступака који представљају „идеални” модел језичког планирања.

Радовановић сматра да етапе нормирања могу бити различите и да зависе од теоријског, али и од практичног приступа језичкој стандардизацији. Овде ћемо се кратко осврнути на Радовановићев приступ. Он, дакле, процес стандардизације види у десет фаза. Прва је фаза селекиија (одабирање) језичнога варијетета на чијој ће се основи заснивати стандардни језик. Одабрани варијетет прво се мора објективно и темељито описати и то, по правилу, захтева писање дескриптивних граматика и опсежних студија о језику, а то је фаза дескрипиије (описивања). Трећа је фаза прескрипиије (прописивање), која одговара Брозовићевом термину свесног нормирања, а подразумева стварање експлицитне норме забележене у прескриптивним нормативним приручницима (граматици, правопису, речницима). Четврта фаза је елаборација (разрађивање), пета акиептуащија (прихватање), шеста имплементација (примењивање), седма експанзија (ширење), осма култивација (неговање), девета евалуација (вредновање) и десета реконструкција (преправљање). ${ }^{1}$ Чини се да све поменуте фазе, по приступу М. Радовановића, имају своје место и у разматрању стабилности српског правописа. Заправо, почетне фазе су јасно омеђене значајним делима, значајним годинама и значајним одлукама, док су неговање, вредновање и преправљање и данас актуелне, и тако ће бити и у времену пред нама. Правописна норма захтева и неговање и вредновање, али и повремено преправљање.

\footnotetext{
${ }^{1}$ Милорад Радовановић је о овоме говорио и писао више пута. Нама се чини најбоље тумачење изнето у предговору књиге Српски језик на крају века (Радовановић 1996: 1-16).
} 


\section{2. Развој и стабилизација српског правописа}

До савременог стања српски правопис је прошао три фазе (периода) и о њима смо говорили више пута (Брборић 2004, Брборић 2015, Брборић 2016). Прва фаза је докодификацијска (довуковска), ${ }^{2}$ после које је уследила фаза кодификације (вуковска), а континуитет је настављен и у посткодификацијској (поствуковској) фази. Докодификацијска фаза нема посебног значаја, завршила се 1818. године и нема никаквог значаја на савремено стање српског правописа и његову стабилност. Потврду за овакав приступ даје нам и Ж. Станојчић, када наводи да у развитку језика, па и правописа, постоји много фаза, али је само почетна тачно датирана и везана за конкретну личност, а да су касније фазе дело многих стваралаца (Станојчић 1994: 26). С појавом Вука Стефановића Караџића наступа, бар када се мисли на континуитет, свеобухватни раскид с пређашњим стањем и потпуно нови период. ${ }^{3}$ „Победом Вукове револуције Срби су постали први словенски народ који је темељито ликвидирао слој излишности ('сало дебелога јера', како се инвентивно изразио Сава Мркаљ, први Србин који је схватио овај проблем)" (Ивић 1966: 28). Чини се да он свесно и несвесно помогао Вуку и припремио терен за оно што ће уследити - потпуна реформа и тријумф нове ере. ${ }^{4}$

Кодификацијски период српског правописа почиње 1818. године и траје равно педесет година (1818-1868), када је скинута и последња његова забрана. Основна карактеристика Вуковог правописа (датог у Српском рјечнику) налази се у Аделунговој теорији и делу Саве Мркаља из 1810. године. Вук заправо бележи само оне гласове који су се заиста изговарали. Овај правопис, чије је јасно начело било „пиши као што говориш”, почива на систему који је функционисао по фонолошко/морфофонолошком принципу (свакој фонеми у говору одговарало је једно слово у писању). Уз то, Вуков правопис имао је велику предност, као и његов избор за основу књижевног језика. Био је лак, није га било потребно дуго учити, довољно је било ослонити се на коректан изговор. Павле Ивић каже да Караџићев графијски систем и данас спада међу најадекватније на свету (Ивић 1994: 48).

За победу Вукових правописних идеја свакако је значајна 1847. година. Можда је до тада Вукова реформа била под знаком питања, али је после ове године успех био сигуран, мада је до њега дошло након доста времена. После 1868. било је потребно ојачати Вукове идеје и разрадити Вукова правописна

2 Довуковска фаза је најдужа и она траје од деветог века, од почетка словенске писмености, па све до 1818. године. Ово је период који се, додуше условно, може временски означити са девет векова.

${ }^{3}$ И пре Вука Караџића било је покушаја да се изврши реформа језика и писма, па тиме и правописа, али су сви покушаји били невеликог домета (Соларић, Стојковић, Венцловић, Обрадовић, Милованов, Орфелин). Свакако је најзначајнији и највреднији покушај Саве Мркаља (1810).

${ }^{4}$ Стицајем различитих околности, сви реформаторски потези до Вука били су неуспешни. Мркаљ се свога става јавно одрекао, Милованов се одао алкохолу, а Орфелинов и Доситејев реформаторски покушај остао је недорађен. 
начела. Средином века је највећи Вуков саборац и следбеник био Ђуро Даничић, али се он није директно бавио правописним питањима.

\section{3. Српски правопис крајем деветнаестог века}

Један целовит ортографски приручник штампан је у Панчеву, а његов аутор је био Стево Чутурило. Реч је о приручнику Српски правопис за школску употребу (1884). Од великог је значаја и студија Љубомира Недића $O$ правопису и интерпункиији. Овај афирматорски рад био је предлог књижевно-уметничкој заједници о решењима конкретних правописних питања, а објављен је 1894. године. Реч је, заправо, о озбиљној правописној студији и из ње видимо да српски правописни проблеми још нису минули и да „њихова правила у нас још нису стално утврђена (...) тако, да се у нас, често, ни два писца не слажу у ономе у чему би требало да су сви сагласни" (Недић 1894: 7). ${ }^{5}$ Вредан пажње је и одељак о правопису у Српској граматици Стојана Новаковића (1894), у којој је Вуков правопис систематски изложен. Наиме, Новаковићева граматика доноси два поглавља посвећена српској ортографији: Главна правила о правопису и одељак Реченични знаџи (Новаковић 1894: 358-405).

Ово је, дакле, био период када је правописна норма консолидована у правом смислу те речи. Јер: „Све до краја XIX века српски правопис је био ствар узуса, а не кодификације” (Ивић 1998: 11). Тако је крајем XIX века дошло до стабилизације правописне норме. Она је, може се рећи, солидно описана и тиме је додатно оснажен реформаторски рад Вука Стефановића Караџића.

Крајем XIX века Хрвати су се правописно и језички у целини приближили Србима. Тако се у Загребу појавио Хрватски правопис Ивана Броза (1892). Он је, то је одмах било очигледно, у целини заснован на вуковским правилима. ${ }^{6}$ О томе, уз садржај приручника најбоље сведоче речи аутора: ,jа сам израдио правила у главноме према начелима којих се држао Вук и Даничић, а само гдјешто одступио сам од њихова писања" (Броз 1892: III). ${ }^{7}$

Вредно је било и то, што се правописа тиче, да је у Маретићевој Граматици и стилистици хрватског или српског језика из 1899. подржан Броз-

\footnotetext{
${ }^{5}$ Рад је имао тридесетак страна и Љ. Недић констатује да многа правописна правила, иако су општеприхваћена, нису чврсто утврђена и да свако пише (и даље) онако како њему изледа да је добро, као и да међу писцима владају недопустиве разлике. Недић јасно захтева да се мора писати уједначено и јединствено и да правопис мора бити један, што вреди и за интерпункцију. Ако је судити по овоме чланку у последњој деценији деветнаестога века, Вуков правопис је прихваћен, али је било још доста нерешених питања, колебања, нејасноћа и неусаглашености.

${ }^{6}$ Како је аутор овога правописа убрзо умро (1893), каснија издања приређивао је Драгутин Боранић. Овај приручник је после био, на неки начин, паралелан са Белићевим. Код Хрвата је био у употреби све до 1960. године.

${ }^{7}$ Овај приручник је после Брозове смрти потписиван неко време као Броз-Боранићев, а касније само као Боранићев.
} 
Боранићев правопис. ${ }^{8}$ Граматика је имала посебан одељак о правопису, где Маретић констатује да сви српски писци пишу „фонетичким” правописом, а хрватски готово сви. Било је то време, када се будуће државно заједништво није назирало, али је зато направљено језичко заједништво, јер је у будућим истојезичним републикама, без резерве, прихваћена Вукова реформа - језичка и правописна.

Хрватски вуковци су у Хрватској крајем XIX века дефинитивно направили нову језичку концепцију која се огледала у копирању и преузимању рада Вука Караџића и српског језичког модела. ${ }^{9}$ Што се тиче територије Црне Горе и Босне и Херцеговине, тамо и није било видљивијих предлога сем прихватања оних које је код Срба „удесио” Вук.

Почетком двадесетог века стабилизацију српског правописа подржали су приручници Милана Петровића. Прво се 1912. појавила Српска граматика с правописом, а две године касније (1914) Српски правопис за средње школе. Обе књиге штампане су у Новом Саду.

\section{4. Правопис с називом „српскохрватски”}

После Првог светског рата, у новим околностима, стабилизацију српског правописа додатно је оснажио највећи лингвиста прве половине двадесетог века Александар Белић. Истина, тада је српски језик преименован у српскохрватски и тај ће назив с мањим одступањима бити званични назив од почетка треће деценије XIX века скоро до његовог краја, тј. до настанка нових (националних) држава од бивших истојезичних југословенских република. Срби су 1923. године добили прави лингвистички правописни приручник, најбољи до тада. Белићев Правопис српскохрватског књижевног језика код Срба је био у употреби све до 1960. године. ${ }^{10}$ Основни текст имао је 300 страница, прву половину су чинила правописна правила, а другу правописни речник.

Тако смо стварањем прве Југославије (1918) имали језик с новим именом, али са два правописа. Разлика између њих није била велика, али је тадашњи режим идући за идејом о ,интегралном југословенству” покушао да разлике уклони. Реаговало је тадашње Министарство просвете и донело Правописно упутство за све основне, средње и стручне школе (1929). У предговору се каже да се у свим школама наше земље користи један правопис, али да у њему има неуједначености и различитих решења, па „наставници не знају

\footnotetext{
${ }^{8}$ Маретићева Граматика дала је велики допринос приближавању хрватског језика српском. Њено прво издање изашло је 1899, друго 1931, а треће 1963. године.

${ }^{9}$ Три су књиге биле од посебног значаја: Хрватски правопис Ивана Броза из 1892. године, Граматика и стилистика хрватскога или српскога језика из 1899. Т. Маретића и Броз-Ивековићев Рјечник хрватскога језика (1901).

${ }^{10}$ Белићев рад на правопису и око њега био је импозантан, као и његова библиографија у целини, која броји 690 радова. Поред самога Правописа, најцеловитије Белићеве студије о правопису су О савременом правопису српскохрватског језика из 1923. године (стр. 1-40) и Борба око намег књижевног језика и правописа, објављена 1935. године (стр. 1-64). Овај правопис је имао четири издања - друго 1930, треће 1934. и четврто 1950. године.
} 
који је правописни начин бољи и који треба употребљавати" (Правописно упутство 1929: 3). Правописно упутство је било, тако нам изгледа, заиста обавезујуће, па је и то допринело скоро потпуној стабилизацији правописних решења. Цитат из предговора Правописног упутства сведочи и његовој строгости и о намери просветних власти да се начин писања потпуно уједначи: „Начин писања изнесен у овом правилнику мора се примењивати у свим новим издањима школских књига. Ниједан уџбеник, било да представља ново издање раније издате књиге, било да се сада први пут издаје, не може бити одобрен за школску књигу, ако није израђен по овим правилима" (Правописно упутство $1929: 3-4){ }^{11}$

Правописно упутство је обавезивало и ауторе правописних приручника, па смо врло брзо имали нова издања и Белићевог и Боранићевог правописа, усклађених са Правописним упутством. Тако смо 1930. стигли до потпуне правописне унификације правописних решења српскохрватског језика.

Правописно заједништво било је нарушено почетком Другог светског рата. Прво је у Хрватској уведен морфофонолошки правопис и учињено видно дистанцирање од Вукових решења, која су била прихваћена код Хрвата пре пола века. Потом су и Срби донели Ново правописно упутство и вратили се на изворног Белића, оног пре Правописног упутства из 1929. Тиме је ослабљен континуитет и непотребно је дошло до дестабилизације правописне норме. Завршетком Другог светског рата разлике су „брзо заборављене” и заједништво из 1930. године поново је било актуелно. Имали смо нова издања предратних правописа, Белићевог и Боранићевог, али се и у Сарајеву 1949. године појавио приручник с насловом Правописна правила и упутства за писање ијекавских гласовних облика Јована Вуковића. Уследила је и књига истог аутора Правопис савременог нашег језика (први дио), Сарајево 1952. Тако је и Босна и Херцеговина ступила на правописну позорницу, што је могло бити најава потоње правописне диференцијације. У Сарајеву се појавио и Правописни приручник српскохрватског-хрватскосрпског језика Светозара Марковића, Мустафе Ајановића и Звонимира Диклића (1972).

\section{5. Правопис и Новосадски договор}

После је уследио Новосадски договор из 1954. године и није спорно да је то био још један покушај унификације српскохрватског правописа. Јасна је била намера власти - вера у заједничку државу, заједнички језик и

\footnotetext{
${ }^{11}$ Правописно упутство је заправо, то се по садржају види, уједначен правописни приручник, тј. компромис између Белићевих и Боранићевих решења. Ево садржаја Правописног упутсmва: Азбука, Писање великих и малих слова, Подела речи на слогове, Одвојено и састављено писање речи, О самогласницима, Књижевни изговори, Писање гласа ,j”, Писање „ћ” и „ч”, „ћ” и „џ”, Писање гласа „Х”, О групама самогласника, Удвајање сугласника, Једначење сугласника по звучности, Групе различитих сугласника, Губљење сугласника, Интерпункција, Одвајање запетом речи, Одвајање запетом реченица, Неодвајање запетом речи, Неодвајање запетом реченица, Други знаци, Транскрибовање туђих речи и имена.
} 
правопис. Истакнути лингвисти, писци и неки културни радници окупљени око Матице српске и Матице хрватске поткрај 1954. године озваничили су Новосадски књижевни договор. Резултат поменутог договора су заједнички правопис и шестотомни речник. У литератури се могу наћи различита тумачења о значају, успесима и дометима договора из Новог Сада. ${ }^{12}$ Направљена је заједничка правописна комисија, било је и несугласица, да би се 1960. године појавио у издању двеју Матица заједнички Правопис српскохрватског књижевног језика.

У сваком случају, Правопис српскохрватског књижевног језика из 1960. године био је у службеној употреби у Србији безмало четири деценије.

Заједништво Срба и Хрвата није дуго трајало. Наиме, Хрвати, односно њихови лингвисти већ 1967. доносе познату Декларацију о називу и положају хрватског књижевног језика и тада је заједништво већ било начето, а то ће се у целини обистинити и његовим формалним раздвајањем у потоњим деценијама.

Ова Декларација нанела је озбиљан ударац правописном заједништву. Наиме, тада је у Хрватској учињено значајно дистанцирање од заједничког језика и правописа и то је, данас је јасно, био увод у касније језичко и правописно раздвајање. Уследила је и појава сепаратног правописа код Хрвата, али је власт реаговала оштро и правописно заједништво је настављено, с нешто оспоравања. ${ }^{13}$ Крај заједништву дефинитивно је потврђен 1986, када је у Хрватској штампан Анић-Силићев правописни приручник.

Последњи покушај истрајавања на заједништву јесу Прилози правопису, који су објављени 1989. као засебна књига, а приређивачи су били Митар Пешикан, Мевлида Караџа-Гарић и Мато Пижурица. ${ }^{14}$

Значајнија правописна елаборација учињена је у Сарајеву у оквиру тамошњег Института за српски језик и књижевност, односно његовог одељења за језик. ${ }^{15}$

С новим међурепубличким споровима и с распадом друге Југославије у последњој деценији двадесетога века, Срби су, поред политичког, добили и правописни плурализам. ${ }^{16}$

${ }^{12}$ Тако, рецимо, Драгољуб Петровић у Школи немуштог језика каже да је савезна влада „пришапнула Матици српској и Матици хрватској да се договоре око правописа и припреме речник језика Срба и Хрвата” (Петровић 1996: 200).

${ }^{13}$ Тако се 1971. године појавио Хрватски правопис с правописним рјечником, чији су аутори били Стјепан Бабић, Божидар Финка и Милан Могуш. Он је у литератури познат под називом лондонац, јер је касније објављен у Лондону.

${ }^{14}$ У раду на отвореним правописним проблемима учествовало је 11 лингвиста из Новог Сада, Београда, Никшића и Сарајева (Павле Ивић, Јован Јерковић, Јован Кашић, Бранислав Остојић, Асим Пецо, Митар Пешикан, Мато Пижурица, Живојин Станојчић, Јосип Баотић, Мевлида Караџа-Гарић и Милан Шипка).

${ }^{15}$ Тако је настало трокњижје: Правописна проблематика у Босни и Херцеговини, 1976; Правописне теме I, 1977. и Правописне теме II, 1978. Ових 1000 страница текста није произвело никакве правописне ломове и може се рећи да је његов допринос нашој правописној (не)сређености остао више него скроман. Вреди поменути рад Ивана Клајна Суштинско и конвенционално у правопису (Клајн 1976: 59-75).

${ }^{16}$ Тада смо добили више правописних приручника, неуједначеног квалитета и то је, на неки начин, дестабилизовало правописну ситуацију. 


\section{6. Национални (нови) правописи у новим околностима}

С распадом СФРЈ нестало је државно, а самим тим и језичко и правописно заједништво истојезичних република. Правописни плурализам појавио се и у Хрватској, а ни Црна Гора и бивша Босна и Херцеговина нису остале имуне.

Истина, у Сарајеву за сада немамо паралелне правописе, већ само Правопис босанскога језика (1996) Сенахида Халиловића и Правопис босанскога језика. Приручник за школе (1999) истог аутора. У Црној Гори, поред поменутих, прво сусрећемо сепаратне правописе, засебног „црногорског” језика аутора Војислава Никчевића, али их експлицитно нико није признавао. Ипак, после политичког осамостаљења озваничен је Правопис ирногорскога језика, иза кога је стало Министарство просвете и науке и експертска комисија за стандардизацију црногорскога језика.

Правописни приручници изван Србије су настојали да нађу макар и минималну разлику и да тиме „озваниче” нови правопис. На површинском плану су то потпуно избегавање екавице и делимично или потпуно избегавање ћирилице. Сама правописна решења доживљавала су мање промене, али суштинских заокрета није било.

Срби су после осам деценија добили правопис с националним именом. Тако је Матица српска, на основу правописне елаборације у Прилозима правопису, објавила Правопис српскога језика (1993), који потписују као приређивачи Митар Пешикан, Јован Јерковић и Мато Пижурица. Приређивачи су у уводној речи јасно објаснили да им није намера да опозову норму из 1960. године, већ да је осавремене, дораде и прилагоде држећи се „континуитета српске књижевнојезичке културе и норме". Уз Правопис из 1960. основ обраде су били већ поменути Прилози правопису из 1989. године. Овај приручник је 2010. године доживео измењено и допуњено издање. У напоменама уз измењено и допуњено издање јасно стоји да је актуелни Правопис (1993) претрпео „знатне измене и допуне”, и то се јасно види у појединим поглављима. Не можемо а да се не запитамо колико су три правописна приручника под окриљем Матице српске претрпела правописних промена. Наиме, Правопис српскохрватског књижевног језика из 1960. био је заједнички и компромисни, с јасном намером државе, подршком језичких стручњака, културне јавности и институција. Правопис из 1993. је нека врста компромиса између решења из заједничког правописа из 1960. и решења која су указивала на његове слабости и која су изнета у Прилозима правопису 1989. године.

Настајањем нових (националних) правописних приручника на подручју бившег српскохрватског језика настају и нека нова правописна решења. Нови правописни приручници су увек доносили извесне (мање) промене неких решења и тиме се, на неки начин, дистанцирали од ранијег заједничког (српскохрватског) правописа. Разлике у правописним решењима између четири правописа су занемарљиве. Скоро би се могло рећи да ни у једном правопису не постоји ништа чега нема у још неком постсрпскохрватском правопису. 
У суштини, ништа се није променило, осим што се језици, тј. правописи, другачије зову.

Сав плурализам ранијег српскохрватског правописа пренео се, на различите начине, у сваки појединачни правопис. У хрватском језику је борба неколико правописа, па чак и између етимолошког и фонолошког правописа, у босанском правопису су присутна сва српскохрватска двојства, без јасних назнака о томе шта би била differentia specifica босанског правописа, у црногорском правопису постоји активно двојство - могу се користити и нова слова, она која имају српски дијалекти, али их нема књижевни језик.

Све посебности које се могу срести у појединачним (националним) правописима не доносе ништа суштински ново, већ су увек посреди она решења која су се сусретала у језичком и правописном заједништву од краја XIX до краја XX века. Отуда је и данас актуелно оно што је о српском правопису крајем XX века написао М. Пешикан, а што се може односити на сва четири „истојезична” правописа: „Од победе Вукове реформе у српској језичкој култури није било никаквих правописних преокрета. Извесна мењања правописних правила имала су карактер дораде, разраде и трагања за решењима која ће бити у што бољем складу с природом књижевног језика, али увек и с његовом вуковском основом. Укупан ток српске језичке културе имао је карактер еволуције, а не прерада, коренитих реформи или преокрета" (Пешикан 1996: 171).

\section{7. Закључак}

Српски правопис, када се осврнемо на последња два века, имао је свој континуитет који је био природан, али је било и нелингвистичких чинилаца. Крајем деветнаестог века српски правопис је био прилично стабилан и његова решења су у највећој мери преузеле касније истојезичне републике у његовом окружењу. Српски правопис је тада имао директан утицај на њих, док је њихов утицај на српски језик био занемарљив. Укупан ток српске правописне историје имао је континуитет и није било радикалних промена од Српског рјечника до данас. У два случаја је српска страна чинила уступке и компромисе, било је то 1930. и 1960. године, али се они нису директно одразили на правописну стабилност. Ипак, одређене промене биле су нужне, пратиле су развој науке и с правом се може говорити о еволутивном току, без великих и наглих промена. Ипак, у наредном периоду је потребно даље планирање и поправка правописне норме и проширивање правописног речника, тј. убацивање актуелних примера. Вредело би нека решења учинити мање компликованим, морали бисмо смањити дублетна решења, али нема потребе за већим заокретима и озбиљнијим променама. 


\section{ЛИТЕРАТУРА}

Белић 1923 [41950]: Александар Белић, Правопис српскохрватског књижевног језика, Београд: Издавачка књижарница Геце Кона.

Брборић 2004: Вељко Брборић, Правопис српског језика у наставној пракси, Београд: Филолошки факултет

Брборић 2008: Вељко Брборић, „Српски правопис у двадесетом веку”, Зборник Матице српске за славистику, 73: 43-55.

Брборић 2011 [22015]: Вељко Брборић, Правопис и школа, Београд: Друштво за српски језик и књижевност Србије.

Брборић 2016: Вељко Брборић, О српском правопису, Београд: Друштво за српски језик и књижевност Србије.

Дешић '2004 [1994]: Милорад Дешић, Правопис српског језика. Приручник за школе, Земун, Нијанса.

Ивић 1994: Павле Ивић, „Књижевни језик као инструмент и продукт ” у: Историја српске културе, Београд.

Ивић 1998: Павле Ивић, „Из прошлости српског правописа” у: $К$ новој писмености, Београд.

Пешикан 1996: Митар Пешикан „Правописна норма ”, у: Српски језик на крају века (ред. Милорад Радовановић), Београд: Институт за српски језик САНУ, 171-179.

Петровић 1912: Милан Петровић, Српска граматика с правописом, Нови Сад.

Петровић 1914: Милан Петровић, Српски правопис за средње школе, Нови Сад.

Правопис 1960: Правопис српскохрватскога књижевног језика, Матица српска - Матица хрватска, Нови Сад - Загреб.

Правопис 1993: Правопис српскога језика, I. Правила и њихови односи, II. Речник уз правопис, Нови Сад.

Правопис 2010: Правопис српскога језика (измењено и допуњено издање), Нови Сад, Матица српска.

Pravopis XJ 22011: Stjepan Babić i Milan Moguš, Hrvatski pravopis (usklađen sa zaključcima Vijeća za normu hrvatskoga standardnog jezika), Zagreb, Školska knjiga.

Правопис ЦЈ 22010: Правопис ирногорскога језика, Подгорица: Министарство просвјете и науке Црне Горе.

Правописно упутство 1929: Правописно упутство за све основне, средње и стручне школе, Београд.

Прилози правопису 1989: (група аутора), приредили: Митар Пешикан, Мевлида Караџа-Гарић и Мато Пижурица, Нови Сад: Матица српска

Радовановић 1996: Милорад Радовановић, „Предговор ”, у: Српски језик на крају века (ред. Милорад Радовановић), Београд: Институт за српски језик САНУ, 1-15.

Станојчић 1994: Живојин Станојчић, „О правопису као изразу начела, и о правописима као приручницима”, Споне XXVI, 5-6, Никшић. 
Халиловић 1996: Senahid Halilovic, Pravopis bosanskoga jezika, Sarajevo: Preporod.

Чутурило 1884: Стево Чутурило, Српски правопис за школску употребу, Панчево.

\author{
Veljko Brborić \\ ORTHOGRAPHIC STABILITY OF SERBIAN LANGUAGE AND INFLUENCE \\ OF THE SURROUNDING LANGUAGES
}

\begin{abstract}
Summary
The work talks about the orthographic stability of Serbian language, how it occured and also about effect on the newly created orthografy in surroundings (Croatian, Bosnian and Montenegrin). Orthographic model created by Vuk was adopted before creation of the first Yugoslavia. However, at the end of the XX century on the territory of the former Serbo-Croatian language national languages and national orthographies were formed as a result of the emergence of new (national) states. In this paper we will try to show how this situation affected the orthographic standard of Serbian language, which changes have occurred and what is their character in Serbian language orthography (2010).

Key words: Serbian language, orthography, orthographic stability, surrounding languages.
\end{abstract}

